\title{
EFFECT OF TEMPERATURE ON SOME BIOLOGICAL ASPECTS AND THE THERMAL REQUIREMENTS OF Diaeretiella rapae (M'INTOSH) (HYMENOPTERA:BRACONIDAE) REARED ON Rhopalosiphum padi L. (HOMOPTERA: APHIDIDAE)
}

\author{
M. Z. Embarak*, H. H. Mahmoud and A. A. A. Salem \\ Plant Protection Res. Institute, Agricultural Research Center, Giza, Egypt. \\ *e-mail: magedzahe@yahoo.com
}

\section{ABSTRACT}

Developmental periods, adult longevity and thermal requirements of Diaeretiella rapae (M'Intosh) were investigated at 18, 20, 22 and $24^{\circ} \mathrm{C}$ constant temperature. The development durations decreased as the temperature increased. At $24^{\circ} \mathrm{C}$ and $18{ }^{\circ} \mathrm{C}$ the periods for egg-mummy period was 8.85 days and 12.79 days; the mummy-adult period was 5.29 days and 7.31 days; the egg-adult period was 14.14 days and 20.10 days; and for the adult longevity was 3.22 days and 4.69 days. The rate of development of all stages increased as the temperature increased from 18 to $24^{\circ} \mathrm{C}$. The developmental threshold of $\mathrm{D}$. rapae estimated using linear regression was 4.5, 2.33, 3.75 and 4.87, while the mean thermal units were 166.8, 117.03, 282.53 and 64.51 for egg-mummy period, mummy-adult period, egg-adult period and adult longevity, respectively. Results revealed that the optimal temperature for growth population of $D$. rapae ranged from 18 to $20^{\circ} \mathrm{C}$.

Key words: Diaeretiella rapae, Rhopalosiphum padi, biological aspects, Temperatures

\section{INTRODUCTION}

The oat bird-cherry aphid, Rhopalosiphum padi L. (Homoptera: Aphididae), is considered as one of the major cereal aphids of cereal crops (Baily, 2007 and Hill, 2008). It causes serious problems on wheat, corn, barley, sorghum, rye, and brome (Modarres Awal, 2002; Jimenez-Martinez et al., 2004; Fabre et al., 2006; Borer et al., 2009 and Wang et al., 2015).

\section{Diaeretiella rapae (M'Intosh)} (Hymenoptera: Braconidae) is considered a common parasitoid of brassica aphids (Sheehan and Shelton 1989b). D. rapae has been observed regularly parasitizing $B$. brassicae, L. pseudobrassicae, and $M$. persicae in canola (French et al., 2001;
Elliott et al., 2014; Jessie 2017b). There is conflicting information regarding the potential importance of $D$. rapae as a parasitoid of $R$. padi and $S$. graminum in winter wheat (French et al., 2001; Elliott et al., 2014).

Temperature may partially affect the effectiveness of a parasitoid as a biological control agent in a particular region. Thus, in addition to factors such as searching ability, host preference, and host suitability, knowledge of developmental responses to temperature should be considered when deciding which one of the parasitoids could be release for biological control (Bernal and Gonzalez, 1993).

The first objective of this study was to determine the influence of temperature 
on developmental periods during immature stages of $D$. rapae, adult longevity, number of adult/female and sex ratio. The second objective was to determine developmental thresholds and temperature requirements for development. Knowledge about these parameters may serve as a benchmark to assess $D$. rapae as a potential parasitoid of the oat bird-cherry aphid, Rhopalosiphum padi.

\section{MATERIALS AND METHODS}

A population of Rhopalosiphum padi (Linnaeus, 1758) was originally collected from a wheat field in Faculty of Agriculture Experimental Farm, Assiut Univ., Egypt in October 2019. The aphids were multiplied on wheat seedlings in a growth chamber at $24 \pm 1^{\circ} \mathrm{C}, 60 \pm 5 \%$ relative humidity and a photoperiod 16: $8 \mathrm{~h}$ (Light: Dark) for several generations. A colony of $D$. rapae was established from mummies of $R$. padi from infested wheat field. Mummified aphids were separated out and kept singly in small glass vials until the emergence of adult parasitoids which were fed on sugar solution.

In order to determine the durations of different parasitoid stages $D$. rapae, on the nymphs of $R$. padi at four temperatures $\left(18,20,22\right.$ and $\left.24^{\circ} \mathrm{C}\right)$, Twenty nymphs of parasitized for each temperature were daily dissected to observe the development of parasitoid stages of $D$. rapae, (egg mummy, Mummy -adult and egg-adult, \% of emergence and sex ratio). At each temperature, twelve aphid colonies each one containing about 150 individuals reared on fresh wheat seedling, into a plastic cage (30 cm long, $25 \mathrm{~cm}$ high, $10 \mathrm{~cm}$ wide). Aphids were exposed to five mated female parasitoids for a 24 h stinging period. Afterwards, parasitoids females were removed and then the aphids at each temperature treatment were checked four times a day for presence of sedentary and bloated mummies. The mummies were collected in glass vials and returned to the same temperature treatment. All mummies were checked daily until parasitoids emergence. Adults were transferred to plastic vials $(25 \times 10 \mathrm{~cm}$ diameter $)$ and kept under the same temperature treatment. Each adult was fed with $15 \%$ honey solution. Individual development time was recorded for the period from egg oviposition to mummy formation, and from mummy formation to adult emergence. Longevity was recorded from adult emergence to its death.

\section{DATA ANALYSIS}

The data were submitted to analysis of variance (ANOVA) and the means were compared by using the least significant difference (LSD) test at $\mathbf{p}=\mathbf{0 . 0 5}$ upon a significant F-test (Duncan's 1955). Obtained results of the parasitoids stages were submitted to regression analysis and the lower threshold temperatures (to) and the thermal units (TU) required for the development of the nymphal stage were estimated according to Mangat (1977).

\section{RESULTS AND DISCUSSION}

\section{Parasitoid response to temperature:}

The results of the effect of different temperatures $18,20,22$ and $24^{\circ} \mathrm{C}$ on developmental periods, adult longevity, number of adult/female and sex ratio of Diaeretiella rapae parasitoid Rhopalosiphum padi on wheat plants are 
shown in (Table 1). There was significant difference amongst development periods of egg-mummy (F=95.40, $P<0.0001)$, mummyadult $(\mathrm{F}=38.65, \mathrm{P}<0.0001)$, egg-adult period $(\mathrm{F}=135.12, \quad P<0.0001)$ and adult longevity $(\mathrm{F}=75.14, \mathrm{P}<0.0001)$ at temperatures of 18 , 20, 22 and $24^{\circ} \mathrm{C}$. Data indicated significant difference in the number of adult/female of D. rapae $(\mathrm{F}=\mathbf{2 8 . 3 8}, \mathrm{P}<\mathbf{0 . 0 0 0 1})$ at $18,20,22$ and $24^{\circ} \mathrm{C}$. In addition, the results demonstrated that the sex ratio of $D$. rapae were 2.17:1, 1.49:1, 1.37:1 and 2.34:1 at 18, 20,22 and $24^{\circ} \mathrm{C}$, respectively. D. rapae showed greater emergence percent at 20 and $22{ }^{\circ} \mathrm{C}$ than 18 and $24^{\circ} \mathrm{C} \quad(\mathrm{F}=9.810$, $\mathbf{P}=0.220$; Fig. 1). Nevertheless, the rise in temperature caused a linear decrease in the number of mummies/female with significant different ( $F=19.502, P=0.048$; Fig. 2).

\section{Rate of development and thermal threshold of $D$. rapae:}

The rate of development, threshold (t0) and thermal units (DD's) of eggmummy period of $D$. rapae at 18, 20, 22 and $24^{\circ} \mathrm{C}$ are depicted in (Table 2 ). The results cleared that the egg-mummy period of $D$. rapae decreased gradually as temperature increased from 18 to $24^{\circ} \mathrm{C}$. Thus, the rate of development egg-mummy increased as well as temperature increase from 18 to $24^{\circ} \mathrm{C}$, achieved 0.078, 0.099, 0.106 and $0.113 \%$ at 18, 20, 22 and $24^{\circ} \mathrm{C}$, respectively. Also, the threshold of egg-mummy period was $4.5^{\circ} \mathrm{C}$ and thermal units were 172.67, 156.40, 165.55 and 172.58 DD's at 18, 20, 22 and $24^{\circ} \mathrm{C}$, respectively with an average of $\mathbf{1 6 6 . 8}$ DD's.

Data in (Table 3) represent the rate of development, threshold (t0) and thermal units (DD's) of mummy and adult period of
D. rapae at different temperature $18,20,22$ and $24^{\circ} \mathrm{C}$. As mention before, the variation of temperature has clear effect on the mummy-adult period of $D$. rapae. The rate of development was positively depended on temperature which recorded $0.137,0.151$, 0.161 and $0.189 \%$ at $18,20,22$ and $24^{\circ} \mathrm{C}$, respectively. Meanwhile, the estimated threshold developmental (to) of mummyadult period was $2.33^{\circ} \mathrm{C}$ and thermal units were 114.55, 116.80, 122.15 and 114.63 DD's at $18,20,22$ and $24^{\circ} \mathrm{C}$, respectively with an average of 117.03 DD's.

Depicted data in (Table 4) cleared the rate of development, threshold (to) and thermal units (DD's) of egg-adult period of D. rapae at different temperature 18, 20, 22 and $24^{\circ} \mathrm{C}$. The obtained data indicated that the period of egg-adult stage of $D$. rapae inversely affected with increasing temperature from 18 to $24^{\circ} \mathrm{C}$ while the rate of development ascending influenced as temperature increase which recorded 0.050 , $0.060,0.064$ and $0.071 \%$ at 18, 20, 22 and $24^{\circ} \mathrm{C}$, respectively. Also, the calculated threshold developmental (t0) of egg-adult period was $3.75^{\circ} \mathrm{C}$, and thermal units were 286.43, 271.38, 285.98 and 286.34 DD's at $18,20,22$ and $24^{\circ} \mathrm{C}$, respectively with an average of 282.53 DD's.

The obtained data in (Table 5) indicated that the rate of development, threshold (to) and thermal units (DD's) of adult longevity of $D$. rapae on four respected temperatures. Likewise of other developmental stages, the duration of adult stage decreased as temperature increase while the rate of development lagged at lower temperature which recorded 0.213 , 0.234, 0.243 and 0.311 DD's at 18, 20, 22 and 
$24^{\circ} \mathrm{C}$, respectively. The estimated threshold of adult development (t0) of $D$. rapae was $4.87^{\circ} \mathrm{C}$. Moreover, the thermal units were 61.58, 64.61, 70.23 and 61.60 DD's at 18, 20, 22 and $24^{\circ} \mathrm{C}$, respectively with an average of 64.51 DD's.

These results were in general agreement with the finding of Eliott et al. (1995), Saleh et al. (2009), Taha et al. (2014) and Basheer et al. (2015) who reported that the developmental periods of different stages of parasitoid $D$. rapae shortened as the temperature increased from $10^{\circ} \mathrm{C}$ to $30^{\circ} \mathrm{C}$. It appears that exposure the parasitoid $D$. rapae to relatively low or high temperature $\left(18^{\circ} \mathrm{C}\right.$ or $\left.24^{\circ} \mathrm{C}\right)$ led to lower emergence percent compared with higher emergence percent at temperature of $20^{\circ} \mathrm{C}$ and $22^{\circ} \mathrm{C}$, in corroborate with Souza et al. (2017) reported decreasing in the emergence percent of $D$. rapae at temperature between $16^{\circ} \mathrm{C}$ and $19^{\circ} \mathrm{C}$ as well as above $25^{\circ} \mathrm{C}$, but stabilized between $19^{\circ} \mathrm{C}$ and $25^{\circ} \mathrm{C}$. The higher number of mummies/female was achieved as temperature decrease, in harmony with Zahra et al. (2012) mentioned the highest number of mummies of $D$. rapae at $10^{\circ} \mathrm{C}$. Souza et al. (2017) indicated that the increase of temperature led to a linear decrease of the parasitoid's total viability. In respect of sex ratio, the results showed that the highest ratio of female obtained at $24^{\circ} \mathrm{C}$ in consistent with Basheer et al. (2015) who found the highest ration of female was recorded (3.642 female : 1 male) at $25^{\circ} \mathrm{C}$. The results show that the temperature influenced the developmental threshold and thermal requirements consequently affect the duration of different stages of $D$. rapae. This is line with the observation of (Bernal and Gonzalez, 1995; Zahra et al., 2012 and Taha et al., 2014).

In conclusion, in the range of $18^{\circ} \mathrm{C}$ to $22^{\circ} \mathrm{C}$, the calculated biological parameters (adult longevity, number of mummies/female, number of adult/female and percentage of emergence) seem to fall in the favorable range for development and multiplication of $D$. rapae parasitoid of $R$. padi.

\section{REFERENCES}

Baily, P. (2007): Pests of Field Crops and Pastures Identification and Control. CSIRO Publishing, Oxford, UK, 520 PP.

Basheer, A., L. Aslan and R. Asaad (2015): Effect of constant temperatures on the biology of the parasitiod Diaeretiella rapae (M'Intsh) when parasitizing the cabbage aphid, Brevicoryne brassicae (L.) under laboratory conditions. Arab J. Plant Prot., 33(1): 72-79.

Bernal, J. and D. Gonzalez (1993): Temperature requirements of four parasites of the Russian wheat aphid Diuraphis noxia. Entomol. Exp. AppL 69:173-182.

Bernal, J., and D. Gonzalez (1995): Thermal requirements of Diaeretiella rapae (M'Intosh) on Russian wheat aphid (Diuraphis noxia Mordwilko, Hom. Aphididae) hosts. J. Appl. Entomol., 119: 273-277.

Borer, E. T.; V. T. Adams; G. A. Engler; A. L. Adams; C. B. Schumann and E. W. Seabloom, (2009): Aphid Fecundity and Grassland Invasion: Invader Life History is the Key. Ecol. Appl., 19: 1187 1196. 
Duncan, D. B. (1955): Multiple range and multiple F-test. Biometrics, 11: 142.

Elliott, N. C.; G. F. Backolou; K. L. Giles, and T. A. Royer (2014): Aphids and parasitoids in wheat and nearby canola fields in central Oklahoma. Southwest. Entomol., 39: 23-28.

Elliott, N.; J. Burd; D. Kindler and J. lee (1995): Temperature effects on development of three cereal aphids parasitoids (Hymenoptera: Aphidiidae). Great Lakes Entomol., 28: 199-204.

Fabre, F., J. S. Pierre; C. A. Dedryver and M. Plantegenest (2006): Barley Yellow Dwarf Disease Risk Assessment Based on Bayesian Modeling of Aphid Population Dynamics. Ecol. Model., 193: 457-466.

French, B. W.; N. C. Elliott; S. D. Kindler and D. C. Arnold (2001): Seasonal occurrence of aphids and natural enemies in wheat and associated crops. Southwest. Entomol., 26: 49-62.

Hill, D. S. (2008): Pests of Crops in Warmer Climates and Their Control. Springer Science, Business Media, UK, 708 PP.

Jessie, W. P. (2017): Effects of interspecific competition and narrowspectrum insecticides on the survival and development of Diaeretiella rapae in Oklahoma winter canola. Ph.D. Dissertation, Oklahoma State University, Stillwater, OK.

Jimenez-Martinez, E. S.; N. A. Bosque-Perez; P. H. Berger and R. S. Zemetra (2004): Life History of the Bird Cherry-oat Aphid, Rhopalosiphum padi (Homoptera: Aphididae), on Transgenic and Untransformed Wheat Challenged with Barley Yellow Dwarf Virus. J. Econ. Entomol., 97: 203-212.

Mangat, B. S. (1977): Thermal threshold and temperature accumulation for the cotton bollworm. J. Tenn. Acad. Sci., 52: 15-16.

Modarres Awal, M. (2002): List of Agricultural Pests and Their Natural Enemies in Iran. 3th Edition, Ferdowsi University Press, 429 PP.

Saleh, A. A. A.; W. G. T. Ghatwary and N. E. Mohamed (2009): Effect of temperature, relative humidity and some biological aspects on parasitoids performance against oleander aphid, Aphis nerii Boyer Fonscolombe (Homoptera: Aphididae). J. Agric. Res., 87: 983-998.

Sheehan, W. and A. M. Shelton (1989): The role of experience in plant foraging by the aphid parasitoid Diaeretiella rapae (Hymenoptera: Aphidiidae). J. Insect Behavior. 2: 743-759. Souza, M. F.; L. F. A. Veloso; M. V. Sampaio and J. A. Davis (2017): Influence of host quality and temperature on the biology of Diaeretiella rapae (Hymenoptera: Braconidae, Aphidiinae). Environ. Entomol., 46(4): 995-1004.

Taha, M. A.; H. Abd-El wahab; I. M. Hanaa; A. A. Abasse and M. Y. M. Inas (2014): Temperature effect on developmental, rate longevity and parasitism of Diaeretiella rapae (M'Intosh) (Hymenoptera: Aphelinidae). J. Plant Prot. and Path., Mansoura Univ., Vol. 5 (2): 273 278.

Wang, H.; K. Wu; Y. Liu; Y. Wu and X. Wang (2015): Integrative Proteomics to Understand the Transmission Mechanism 
Ass. Univ. Bull. Environ. Res. Vol. 24 No. 1 March 2021

of Barley Yellow Dwarf Virus-GPV by Its

Insect Vector Rhopalosiphum padi. Sci.

Rep., 5:10971.

Zahra, T.; A. A. Talebi and E.

Rakhshani (2012): Temperature-Dependent
Functional Response of Diaeretiella rapae (Hymenoptera: Braconidae), a Parasitoid of Diuraphis noxia (Hemiptera: Aphididae). J. Entomol. Res. Soc., 14(1): 31-40. 
Table (1): Effect of different temperatures on some biological aspects of $D$. rapae parasitoid of $R$. padi.

\begin{tabular}{|c|c|c|c|c|c|c|}
\hline \multirow{2}{*}{ 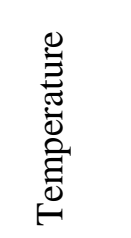 } & \multicolumn{4}{|c|}{ Biological aspects of D. rapae (days) } & \multirow{2}{*}{ 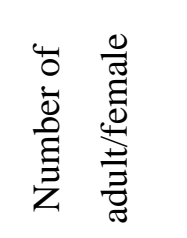 } & \multirow{2}{*}{$\begin{array}{c}\text { Sex ratio } \\
(\mathrm{F}: \mathrm{M})\end{array}$} \\
\hline & $\begin{array}{c}\text { Egg-mummy } \\
\text { period }\end{array}$ & $\begin{array}{l}\text { Mummy- } \\
\text { adult period }\end{array}$ & $\begin{array}{c}\text { Egg-adult } \\
\text { period }\end{array}$ & $\begin{array}{l}\text { Adult } \\
\text { longevity }\end{array}$ & & \\
\hline $18^{\circ} \mathrm{C}$ & $12.79 \pm 0.26 \mathrm{a}$ & $7.31 \pm 0.11 \mathrm{a}$ & $20.10 \pm 0.24 \mathrm{a}$ & $4.69 \pm 0.07 \mathrm{a}$ & $14.97 \pm 1.09 \mathrm{a}$ & $2.17: 1$ \\
\hline $20{ }^{\circ} \mathrm{C}$ & $10.09 \pm 0.14 \mathrm{~b}$ & $6.61 \pm 0.21 \mathrm{~b}$ & $16.70 \pm 0.29 \mathrm{~b}$ & $4.27 \pm 0.08 \mathrm{~b}$ & $9.81 \pm 0.55 \mathrm{~b}$ & $1.49: 1$ \\
\hline $22^{\circ} \mathrm{C}$ & $9.46 \pm 0.13 \mathrm{c}$ & $6.21 \pm 0.11 \mathrm{c}$ & $15.67 \pm 0.20 \mathrm{c}$ & $4.10 \pm 0.04 \mathrm{~b}$ & $9.45 \pm 0.67 \mathrm{~b}$ & $1.37: 1$ \\
\hline $24{ }^{\circ} \mathrm{C}$ & $8.85 \pm 0.14 \mathrm{~d}$ & $5.29 \pm 0.07 \mathrm{~d}$ & $14.14 \pm 0.11 \mathrm{~d}$ & $3.22 \pm 0.09 \mathrm{c}$ & $5.62 \pm 0.39 \mathrm{c}$ & $2.34: 1$ \\
\hline $\operatorname{LSD}_{0.05}$ & 0.51 & 0.39 & 0.62 & 0.20 & 2.05 & \\
\hline$F$ value & 95.40 & 38.65 & 135.12 & 75.14 & 28.38 & \\
\hline$P$ & $<0.0001$ & $<0.0001$ & $<0.0001$ & $<0.0001$ & $<0.0001$ & \\
\hline
\end{tabular}

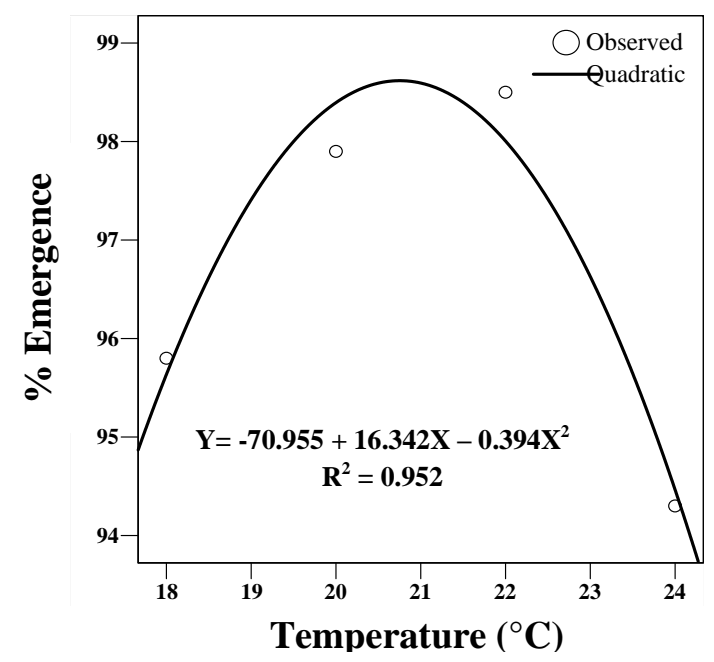

Fig. 1: Fitted regression curve for the emergence percent of Diaeretiella rapae, as a function of temperature.

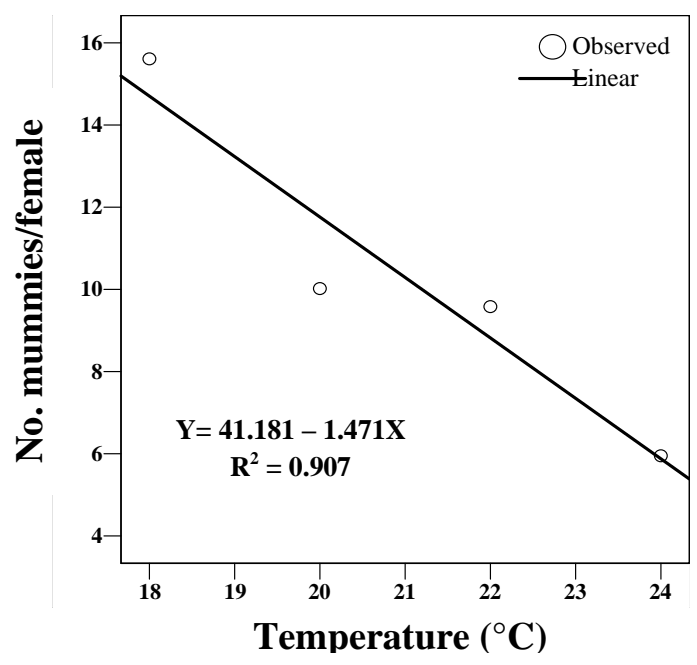

Fig. 2: Fitted linear regression for the number of mummies/female of Diaeretiella rapae, as a function of temperature. 
Table (2): Rate of development, threshold (to) and thermal units (DD's) of egg- mummy period

\begin{tabular}{|c|c|c|c|c|}
\hline Temperature & Egg-mummy period & Rate of development (\%) & $\begin{array}{c}\text { Threshold } \\
\text { development }\end{array}$ & Thermal units (DDs) \\
\hline $18{ }^{\circ} \mathrm{C}$ & $12.79 \pm 0.26 \mathrm{a}$ & 0.078 & \multirow{3}{*}{4.5} & 172.67 \\
\hline $20^{\circ} \mathrm{C}$ & $10.09 \pm 0.14 \mathrm{~b}$ & 0.099 & & 156.40 \\
\hline $22^{\circ} \mathrm{C}$ & $9.46 \pm 0.13 \mathrm{c}$ & 0.106 & & 165.55 \\
\hline $24^{\circ} \mathrm{C}$ & $8.85 \pm 0.14 \mathrm{~d}$ & 0.113 & & 172.58 \\
\hline Average & & & & 166.8 \\
\cline { 1 - 2 }
\end{tabular}

of D. rapae parasitoid of $R$. padi.

Table (3): Rate of development, threshold (t0) and thermal units (DD's) of mummy - adult period of $D$. rapae parasitoid of $R$. padi.

\begin{tabular}{|c|c|c|c|c|}
\hline Temperature & mummy-adult period & Rate of development (\%) & $\begin{array}{c}\text { Threshold } \\
\text { development }\end{array}$ & Thermal units (DDs) \\
\hline $18^{\circ} \mathrm{C}$ & $7.31 \pm 0.11 \mathrm{a}$ & 0.137 & \multirow{3}{*}{2.33} & 114.55 \\
\hline $20^{\circ} \mathrm{C}$ & $6.61 \pm 0.21 \mathrm{~b}$ & 0.151 & & 116.80 \\
\hline $22^{\circ} \mathrm{C}$ & $6.21 \pm 0.11 \mathrm{c}$ & 0.161 & & 122.15 \\
\hline $24{ }^{\circ} \mathrm{C}$ & $5.29 \pm 0.07 \mathrm{~d}$ & 0.189 & & 114.63 \\
\hline Average & & & & 117.03 \\
\hline
\end{tabular}

Table (4): Rate of development, threshold (to) and thermal units (DD's) of egg- adult period of $D$. rapae parasitoid of $R$. padi.

\begin{tabular}{|c|c|c|c|c|}
\hline Temperature & Egg-adult period & Rate of development (\%) & $\begin{array}{c}\text { Threshold } \\
\text { development }\end{array}$ & Thermal units (DDs) \\
\hline $18^{\circ} \mathrm{C}$ & $20.10 \pm 0.24 \mathrm{a}$ & 0.050 & \multirow{3}{*}{3.75} & 286.43 \\
\hline $20^{\circ} \mathrm{C}$ & $16.70 \pm 0.29 \mathrm{~b}$ & 0.060 & & 271.38 \\
\hline $22^{\circ} \mathrm{C}$ & $15.67 \pm 0.20 \mathrm{c}$ & 0.064 & & 285.98 \\
\hline $24^{\circ} \mathrm{C}$ & $14.14 \pm 0.11 \mathrm{~d}$ & 0.071 & & 286.34 \\
\hline Average & & & & 282.53 \\
\hline
\end{tabular}

Table (5): Rate of development, threshold (t0) and thermal units (DD's) of adult longevity of $D$. rapae parasitoid of $R$. padi.

\begin{tabular}{|c|c|c|c|c|}
\hline Temperature & adult longevity & Rate of development $(\%)$ & $\begin{array}{c}\text { Threshold } \\
\text { development }\end{array}$ & Thermal units (DDs) \\
\hline $18{ }^{\circ} \mathrm{C}$ & $4.69 \pm 0.07 \mathrm{a}$ & 0.213 & \multirow{2}{*}{4.87} & 61.58 \\
\hline $20^{\circ} \mathrm{C}$ & $4.27 \pm 0.08 \mathrm{~b}$ & 0.234 & & 64.61 \\
\hline $22{ }^{\circ} \mathrm{C}$ & $4.10 \pm 0.04 \mathrm{~b}$ & 0.243 & & 70.23 \\
\hline $24{ }^{\circ} \mathrm{C}$ & $3.22 \pm 0.09 \mathrm{c}$ & 0.311 & & 61.60 \\
\hline Average & & & & 64.51 \\
\hline
\end{tabular}


تأثير درجة الحرارة على بعض الخصائص الحيوية والاحتياجات الحرارية لطفيل Diaeretiella rapae (M'Intosh) (Hymenoptera:Braconidae)

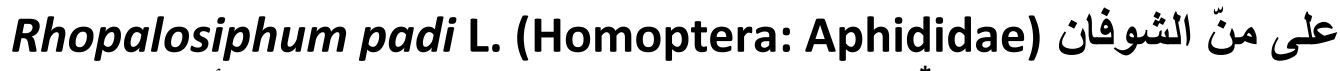

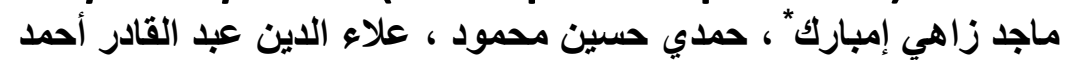
معهز بحوث وقائة النباتات ـ مركز البحوث الزراعية ـ الجيزة - جمهورية مصر العربية.

*e-mail: magedzahe@yahoo.com

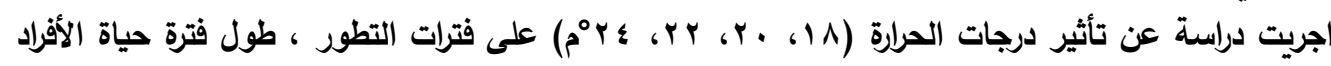

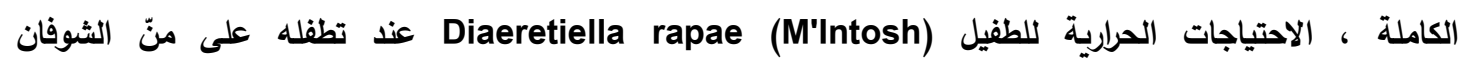
.Rhopalosiphum padi

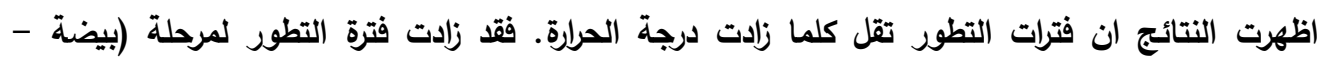

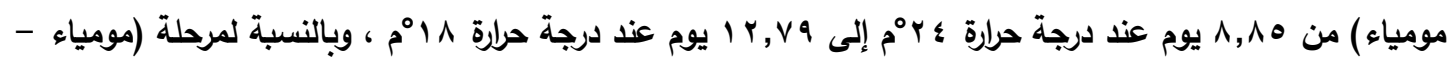

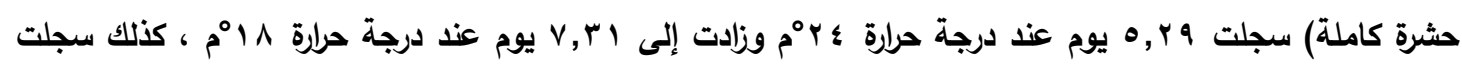

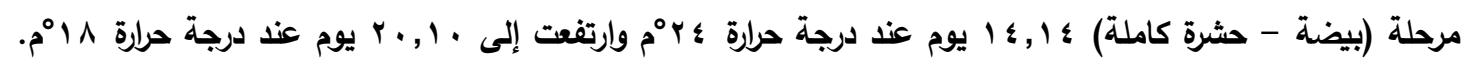

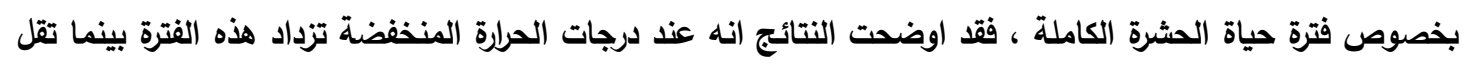

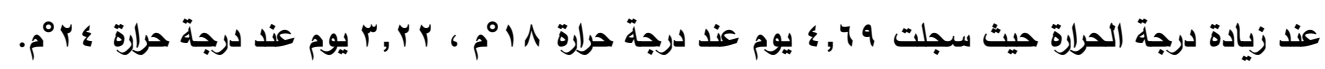

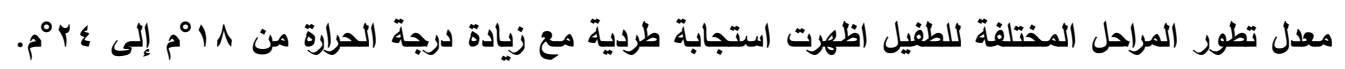

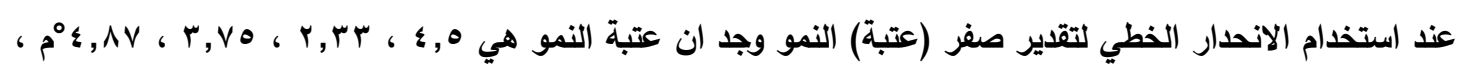

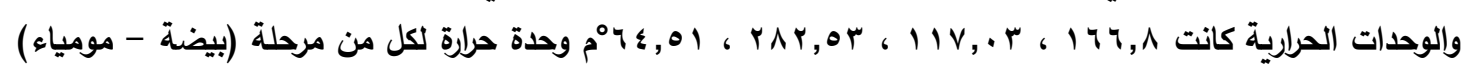

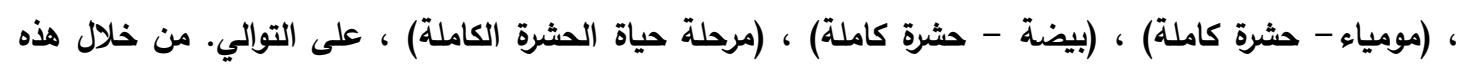

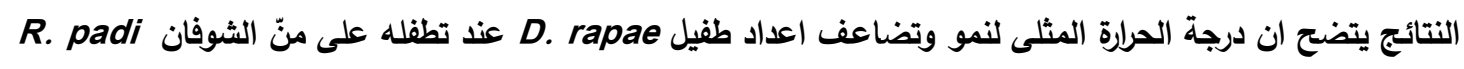

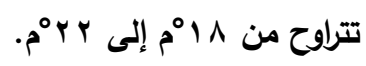

